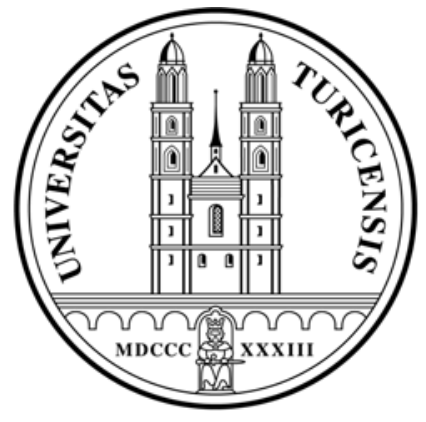

Institute for Empirical Research in Economics

University of Zurich

Working Paper Series

ISSN 1424-0459

Working Paper No. 500

Prosperous Pacifists

The Effects of Development on Initiators and Targets of Territorial Conflict

Erik Gartzke and Dominic Rohner

September 2010 


\title{
Prosperous Pacifists
}

\section{The Effects of Development on Initiators and Targets of Territorial Conflict*}

\author{
Erik Gartzke $\quad$ Dominic Rohner $\ddagger$
}

1 September 2010

\begin{abstract}
Scholars have suggested several ways in which economic development could affect interstate conflict. Supply side arguments view modern economies as more difficult to subdue or exploit through force (i.e., development creates states that are "bitter pills"). The demand side perspective argues in contrast that development lessens the appeal of conquest among potential aggressors (i.e., development creates "prosperous pacifists"). We offer a formal model that isolates contrasting consequences of development for initiators and targets. We use a directed dyad research design to test hypotheses drawn from the model on measures of territorial conflict. The development of potential initiators, not of possible targets, discourages conflict among nations.
\end{abstract}

${ }^{*}$ We wish to thank Tanisha Fazal, Kristian S. Gleditsch, Pablo Pinto, and Paul Senese for valuable comments. We dedicate this paper to Paul, whose work inspired this project, and who left us much too early. A previous draft of this paper was presented at the University of Essex. Please send all correspondence to the first listed author. A STATA "do" file replicating data manipulation and analysis is available from the authors upon publication.

${ }^{\dagger}$ University of California, San Diego, 9500 Gilman Dr., La Jolla, CA 92093-0521. e-mail: egartzke@ucsd.edu.

${ }^{\ddagger}$ University of Zurich, Department of Economics, Muehlebachstrasse 86, 8008 Zurich, Switzerland. e-mail: drohner@iew.uzh.ch. Financial support from the Swiss National Science Foundation (SNF grant no. 100014-122636) is gratefully acknowledged. 


\section{Introduction}

Economic liberals have long argued that development would eventually lead nations to abandon war (Paine 1986[1776], Cobden 1903[1867], Angell 1933). Evidence of a developmental peace remains tentative, however, even while existing explanations pose a range of causal logics. In particular, developmental peace arguments offer contrasting claims about whether economic forces work largely through diminishing the interest of states in aggression or by enhancing deterrence or defense.

Economic development could reduce the supply of targets, making some states harder to conquer or profitably subdue. In the information age, wealth is mobile and can leave the scene of an attack. Conquest of economies heavily dependent on regular infusions of capital and on willing labor with perishable skills makes little sense if occupation scares away investors or creative workers (Rosecrance 1985,1996$).{ }^{1}$ Modern production processes are also distributed globally, making vertical integration through subjugation difficult (Brooks 1996, 2005). These arguments treat development as a "bitter pill," creating polities that other nations find unappealing as targets of aggression.

Alternately, development could affect the demand for conquest if industrialized economies no longer benefit from territorial holdings, or find deploying occupying armies excessively expensive. Modernity could make the spoils of victory less valuable, either by lowering the price of commodities and raw materials obtainable through territorial aggression, raising the labor cost of occupation and wealth extraction, or by fostering other mechanisms for obtaining needed goods, such as global economic markets (Gartzke 2006, 2007). Demand side arguments imply that development creates "prosperous pacifists," states that are much less inclined to pursue objectives as dispute initiators.

We construct a formal game theoretic model in which development affects states' decisions to devote effort to domestic production or foreign acquisition. Economic development decreases a state's willingness to expend increasingly valuable labor to capture capital through the conquest of territory. Our efforts to model resource competition differentiate between attributes of the initiator and target, leading to novel hypotheses about how development affects conflict propensity. By

\footnotetext{
${ }^{1}$ There are other reasons why development might make states difficult to conquer. Nationalism, for example, creates territories that are harder to police and administer (Moore 1966, Gellner 1983, Tilly 1992, Van Evera 1994). While logically separable from our argument, we acknowledge and address these other causes in the empirical section. Note too, that in most cases nationalism is said to operate like a "bitter pill," making certain nations more difficult and unappealing as targets of conquest. As we show later, this perspective is less compelling theoretically or empirically.
} 
using a directed dyadic research design, we are also able to adjudicate among contrasting theoretical consequences of the nature of economic production and its impact on the motives to use force.

The model and our results tell a cohesive story about the effect of development on international cooperation and conflict. Rather than making states less likely to fight under all circumstances, development actually makes it easier for states to deploy armies far from home. Conversely, economic development diminishes the interest of potential initiators in contests over resources or territory (Gartzke \& Rohner 2009). Development does not inoculate states from the danger of occupation. Indeed, economically developed countries appear no less subject to attack. Rather, development creates states that are reluctant to appropriate resources, perhaps because it is cheaper to buy inputs to production through global markets, while occupying armies are increasingly expensive. ${ }^{2}$

\section{Studies of Economic Development and Interstate Conflict}

Theories of economic development and conflict follow the waterways of established intellectual tradition, though these arguments are often so embedded in larger theoretical frameworks that their contributions - even their presence - often go unnoticed. Virtually every major school of thought in international relations treats economic development as a direct or indirect determinant of war or peace. Unfortunately, there is no consensus about the details, or even the basic content and consequences, of causal mechanisms; plausible claims point in seemingly contradictory directions.

Thucydides famously attributed the Peloponnesian War to "the growth of the power of Athens, and the alarm which it inspired in Lacedaemon" (1960, page 46). While widely interpreted as evidence of his bonafides as realist progenitor, Thucydides' statement also illustrates his economic determinism, and the dependence within classical realist theory on external (usually economic) processes of change. The growth of Athenian power derived from its status as a trading state. Without economic development, Thucydides, and classical realism, largely lacks a dynamic element.

Where Thucydides sees danger, other scholars are more sanguine. Optimism about economic

\footnotetext{
${ }^{2}$ Culture or identity create ties to territory that affect conflict independent of economic valuation (c.f. Jepperson et al. 1996). The analysis here is not meant to discount culture or identity arguments. Instead, since we lack a theory of systematic variation in these immaterial factors (Henderson 1997), we leave their assessment to future research.
} 
development gathered steam with the industrial revolution. ${ }^{3}$ Cobden, for example, argued that "Commerce is the grand panacea, which, like a beneficent medical discovery, will serve to inoculate with the healthy and saving taste for civilization all the nations of the world" (1903[1867], page 34). Cobden also offers the often repeated claim that development makes war more expensive. "Should war break out between two great nations I have no doubt that the immense consumption of material and the rapid destruction of property would have the effect of very soon bringing the combatants to reason or exhausting their resources" (Cobden 1903[1867], page 355). The argument is peculiar in part because development almost certainly has the effect of increasing state resources.

Witness to dramatic growth in economic livelihood, banking, trade, and travel at the end of the nineteenth century, Norman Angell argued "that it is impossible for one nation to seize by force the wealth or trade of another - to enrich itself by subjugating, or imposing its will by force on another; that, in short, war, even when victorious, can no longer achieve those aims for which peoples strive" (1933, pages 59-60). Conquered states with modern economies cannot be looted for anything of real value. Capital flight robs the invader of the assets it seeks to obtain. Indeed, continued productivity depends on enticing mobile inputs to production with good government and the honoring of contracts, behaviors that are at odds with conquest. Even if one could get the economy running, global trade markets make occupation a relatively expensive form of production.

Where centrist liberal intellectuals saw the march of progress and peace, scholars to the left and right heard the drumbeat of war. Hobson (1938[1905]), in particular, identifies capitalist development with imperialism. While Cobden viewed capitalism and the rising middle class as a brake on militarism, Hobson emphasized the consequences of an unequal distribution of income and of private control over mobile wealth. Capital accumulation and the resulting thirst for markets would lead to violence. "Imperialism - whether it consists in a future policy of expansion or in the rigorous maintenance of all those vast tropical lands which have been ear-marked as British spheres of influence -implies militarism now and ruinous wars in the future" (1938[1905], page 130). ${ }^{4}$

\footnotetext{
${ }^{3}$ See Blainey (1973, pages 18-32) for an lucid discussion of the Manchester school of liberal economic peace.

${ }^{4}$ For Hobson, imperialism can be thwarted by democracy. "The power of the imperialist forces within the nation to use the national resources for their private gain, by operating the instrument of the State, can only be overthrown by the establishment of genuine democracy" (1938[1905], page 360). Long (1996) also shows that Hobson was pivotal in redirecting liberalism away from laissez-faire economic theory and toward a focus on international organizations.
} 
With revolution slow to materialize, Lenin (1965) and other Marxists sought to associate capitalism with empire. The colonial system temporarily delayed the dialectic, but the inevitable result was just around the corner; competition to capture markets would lead to war and proletarian revolution. 5 "The growth of capitalism, spreading out rapidly over a reconstituted Europe ... opened up a new period of storm and danger among the nations of Europe" (Luxemburg 1971, page 128).

Realists shared the distain of Marxists for liberal political economics. Carr (1939) mounted a visceral attack on liberal theory. ${ }^{6}$ Development increases state resources, allowing sovereigns to buy more weapons. The Marxist struggle for markets also has an analogue in the realist preoccupation with the zero-sum struggle for power. ${ }^{7}$ The two "isms" part company in how they order events, and in what they emphasize. Marxist preoccupation with economics implies that politicians are just capitalist toadies. Realists reverse the causal arrow, promoting security above "low" economic politics. Thus, while Marxists saw capitalist development as inevitably descending to war, the realist view is qualified by how states choose to play their capitalist cards in the security sphere.

Cold war conditions emphasized relative, rather than absolute, power, diminishing the perceived importance of development as a determinant of war or peace. Arms racing, deterrence, and balancing supplanted imperialism and growth as key dynamic mechanisms in international relations. ${ }^{8}$ Some scholars bucked this cold war trend, however, retaining development in the driver's seat of history. As before, both optimists (Kuznets 1966, 1973; Rosecrance 1985, 1996) and pessimists (Choucri \& North 1975,1989; Kennedy 1989$)^{9}$ coexisted in a common analytical universe. ${ }^{10}$ The

\footnotetext{
${ }^{5}$ Rowe (1999) argues that rising factor prices in periods of heated development lead to a sense of relative decline, insecurity, and preventive war. Yet, military innovation may adjust factor utilization in response to changes in supply.

6 "What confronts us in international politics to-day is, therefore, nothing less than the complete bankruptcy of the conception of morality which has dominated political and economic thought for a century and a half. ... The synthesis of morality and reason, at any rate in the crude form in which it was achieved by nineteenth-century liberalism, is untenable" (Carr 1939, page 62). Carr's commentary, of course, leaves open the possibility of refining liberal theory.

7 "Marxists and realists share a sense of the importance of contracting frontiers and their significance for the stability and peace of the system. As long as expansion is possible, the law of uneven growth (or development) can operate with little disturbing effect on the overall stability of the system. In time, however, limits are reached .... The clashes among states for territory, resources, and markets increase in frequency and magnitude and eventually culminate in hegemonic war" (Gilpin 1981, page 201). Yet, where Marxists see impeded growth as the critical dynamic in the timing of crisis, realists argue that states can stave off crisis through internal and/or external balancing.

${ }^{8}$ Inattention to the economic "fundamentals" contributed to the failure of most international relations experts and Sovietologists to anticipate the collapse of the Soviet system (Gaddis 1992a, 1992b, 2005a, 2005b; Strayer 1998). This inattention is more than a little ironic, given the critical role in Marxist ideology to economic determinism.

${ }^{9}$ Zuk (1985) finds no evidence of lateral pressure. Tir \& Diehl (1998) report that "there are substantial limits to the validity of extending overcrowding arguments to the context of interstate relations" (1998, page 336).

${ }^{10}$ Mueller (1989) argues that populations have simply changed their attitude about war, no longer finding fighting
} 
challenge has been to find ways of adjudicating contrasting claims, given that anecdotal support appears ubiquitous. In the literature on development and conflict, quantification of key variables had been widely practiced, though researchers seldom went further than using data in tabular form for descriptive purposes. When statistical methods were applied, it was discovered that little or no empirical basis existed for any relationship between development and interstate conflict (Richardson 1960, East \& Gregg 1967, Rummel 1967, Thompson 1982, Maoz \& Russett 1992).

In apparent contrast, the level of economic development is viewed as one of the best and most reliable predictors of intrastate conflict (Collier \& Hoeffler 2002, Elbadawi \& Hegre 2008, Elbadawi \& Sambanis 2002, Ellingsen 2000, Fearon \& Laitin 2003, Hegre, Ellingsen, Gates \& Gleditsch 2001). Fearon \& Laitin find that GDP/pop. "is strongly significant in both a statistical and substantive sense" even when controlling for region, ethnicity, religion, prior conflict, territory, intervention, regime type, and stability (2003, page 83 ). "It has been repeatedly observed that the onset of internal wars is related to the level of economic development" (Wallensteen et al. 2001, page 21).

A closer look at arguments linking development to war or peace suggests a way to reconcile the enigma of contrasting domestic and international results. Rosecrance (1985) offers an optimistic vision of developmental peace reminiscent of Cobden, Bastiat, and other nineteenth century liberals. "Land, which is fixed, can be physically captured, but labor, capital, and information are mobile and cannot be definitively seized; after an attack, these resources can slip away like quicksilver" (Rosecrance 1996, page 48). In contrast, Ashley claims that "war is mainly explicable in terms of differential growth..." (1980, page 3). The incompatibility of these two perspectives is largely only apparent. The declining value of territory relative to other inputs to production should discourage territorial conquest. It does not follow that development eliminates all motives for warfare. ${ }^{11}$

Brooks $(1999,2005)$ presents several arguments for why modern economies discourage conquest. First, labor mobility allows workers with globally marketable skills to flee occupied territories. Second, conquered assets may be difficult for the conqueror to repatriate. Third, invaders scare away investment, leading to capitalization problems for industries with short product cycles. ${ }^{12}$

acceptable. Kaysen (1990) critiques Mueller, suggesting instead that development changes structure, not preferences.

${ }^{11}$ Boehmer \& Sobek (2005) provide evidence that development has curvilinear effects on conflict at the state level. Hegre (2000) shows that development conditions the liberal peace. See, Lemke (2003b) for a review of the literature.

${ }^{12}$ Occupiers cannot credibly commit not to steal from investors and firms (Olson 1993, McGuire \& Olson 1996). 
Fourth, coercion tends to stifle innovation and entrepreneurialism, essential engines of modern economies. While plausible, the lack of a statistical association between development and conflict suggests the need to treat these claims with caution. Brooks (1999) does not directly address the possibility that development increases the willingness or ability of states to fight. The jet age has made reaching out to touch, and to harm, distant adversaries easier and arguably more decisive. ${ }^{13}$

Like other students of development, Brooks $(1999,2005)$ assumes that states fight over territory or resources. While resource competition is one motive for conflict, states can also compete over domestic or international outcomes, the trade surplus, and policy prerogatives. What a state is entitled to decide or impose on others can often be as valuable as where it is able to collect taxes. The absence of a discussion about how modernity affects the policy sphere in international politics suggests that only part of the impact of development is being addressed. Similarly, the profitability of invasion is strangely assumed to be an attribute of targets rather than of potential attackers.

\section{How Economic Development Influences Interstate Conflict}

The presence of plausible but conflicting theoretical assertions, and the ambiguity of available evidence implies the need for greater logical precision. We develop several versions of a formal model to clarify predictions and to identify which underlying assumptions are driving particular conclusions (Morton 1999, Osborne \& Rubinstein 1994). The two-player game represents countries.

Elsewhere, we present a single, integrated model in which two players optimize over the three options of domestic production, territorial conquest, or policy coercion (Gartzke \& Rohner 2009). Here, we focus on the more complex question of which states initiate contests. We build a gametheoretic model with a fully specified production function and where players have the choice over a continuous range of fighting intensities. Instead of allowing an overall assessment of the impact of economic development, this framework instead permits us to compare the effects of an acceleration of the development level of a country compared with the accelerated development of an opponent. Hence, we are able to distinguish supply-side versus demand-side effects of development for conflict.

\footnotetext{
${ }^{13}$ Boulding (1962) pioneered the notion of a loss-of-strength gradient in which distance decays capabilities. Buhaug \& Gleditsch (2006) show that distance continues to reduce conflict, though development has weakened the decay.
} 


\subsection{A Model of Territorial/Resource Conflict}

Territorial conflict is characterized as mutual attempts to appropriate inputs to production. Consider a dyad in which two countries decide how to spend their overall (labor) time (normalized to equal 1) between productive $(L)$ and appropriative $(F)$ activities. More formally, we can represent the problem as the "time constraint" in equation (1), a standard budget constraint. Players have a given allocation of labor time that they can use for different activities. The framework is similar to a consumer choice model, where players have a given budget to spend on different goods:

$$
L_{i}+F_{i}=1
$$

where $L=$ the proportion of the time endowment spent on productive activity (making things), and $F=$ the proportion of the time endowment spent on appropriation (stealing stuff), $i=1,2$.

Appropriation involves coercive acts intended to alter the distribution of inputs or outputs. Countries aim to obtain "land" and other tangible factors of production. Appropriation typically constitutes a zero-sum transfer with a resulting deadweight loss to the aggregate (total) production.

Attempts at appropriation need not lead automatically to fighting. As bargaining theories of war make clear, competition is a necessary but not sufficient condition for the outbreak of fighting (Fearon 1995, Wagner 2000, Powell 2002, Slantchev 2003). Yet, the converse must also be true; the mutual absence of appropriation is sufficient for war not to occur. Higher incentives for states to seek to appropriate from other states increase the risk that war might occur, should bargaining also fail. Increases in resources devoted to appropriation make nations "ripe" for conflict much as arms racing (Wallace 1979, Morrow 1989, Glaser 2004) or alliance formation (Levy 1981, Smith 1995, Leeds 2003) are said to presage war. More formally, we represent the situation in the following way.

$$
R=R(\stackrel{+}{F})
$$

where $R=$ the probability (risk) of inter-state war $(0 \leq R \leq 1)$.

Even in bargaining theory, the risk of a contest is at least weakly increasing in appropriation $(F)$. Many states lack the ability to fight (limited weapons, geographically distant). Any monotonically 
increasing function of $R$ in terms of $F$ can be used, but bargaining theory implies that even for a maximum level of $F=1$, the likelihood of conflict $R$ is far below 1. At some threshold, additional increases in capability levels are a poor predictor of variation in conflict. We introduce an arbitrary threshold $z$ on the ex ante probability of fighting, $R$, where $0 \leq z<1$ (the quantity $(1-z)$ can be interpreted as the stochastic component of war). One could adopt a logarithmic or exponential function such as $R=z \ln (\omega+F)$, or $R=z F^{\phi}$, where $\omega \geq 1, \phi>0$. For example, Figure 1 plots $R$ in terms of $F$ when $R=\frac{z}{1+\exp (\gamma-\mu F)}$, with parameter values of $\gamma=6, \mu=12$ and $z=0.7$.

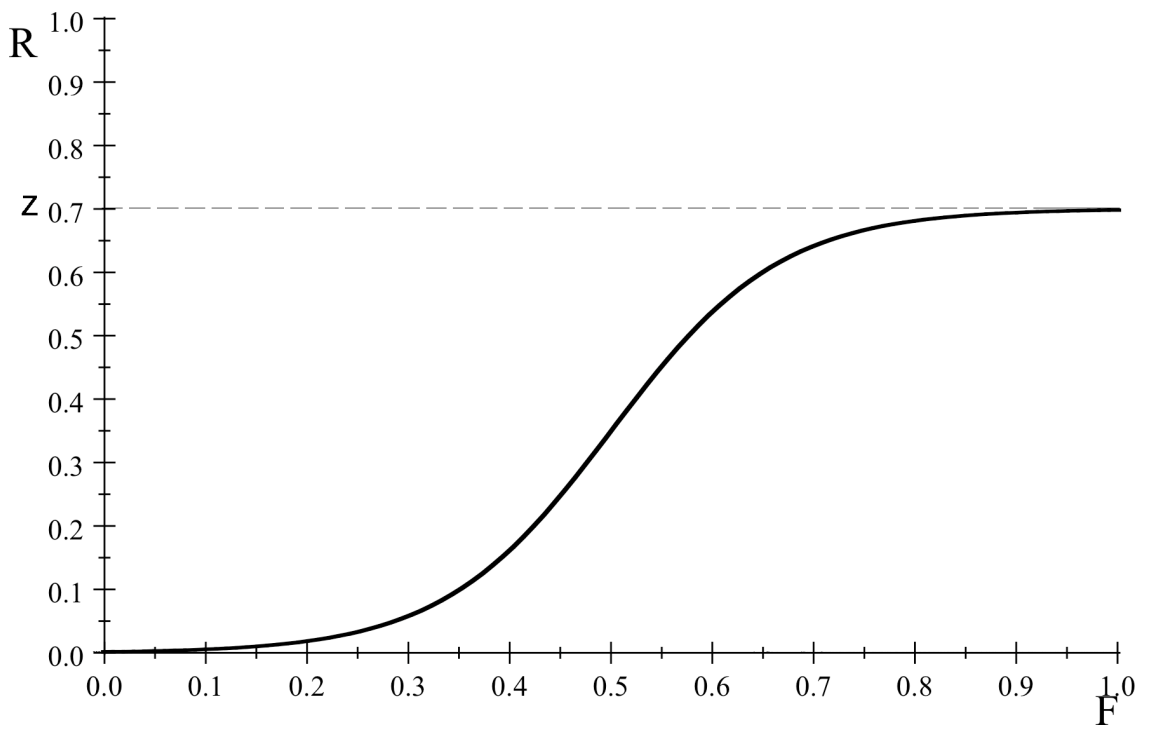

Figure 1: The link between appropriative activities and fighting

In the example in Figure 1, the sigmoidal shape of the function means that small changes in small values and in big values of $F$ have little effect on $R$, but comparable changes in middle-range values of $F$ lead to more substantial changes in $R$. Since we are primarily interested in how motives for aggression vary with economic attributes of states, we keep things simple by treating $F$ and $R$ as equivalent, while noting that our findings generalize to any continuous, monotonic function.

Only one output good, $y$, is produced, using two inputs, labor $(L)$ and capital $(K)$. Whereas $L$ is the choice variable, for the purposes of intuition, think of $K$ as an endowment of several forms of capital such as physical capital (infrastructure, machines, etc) and productive land. The respective production functions of the two countries in the model are displayed in equations (3a) and (3b). 


$$
\begin{aligned}
& y_{1}=\alpha L_{1}^{a} K_{1}^{b} \\
& y_{2}=\beta L_{2}^{c} K_{2}^{d}
\end{aligned}
$$

where $\alpha, \beta=$ total factor productivities, and where $a, b, c, d=$ parameters.

All factors are assumed to exhibit decreasing marginal returns (i.e. $a<1, b<1, c<1, d<1$ ).

Territorial conflict involves attempts to appropriate land and physical capital from an opponent. Equations (4a) and (4b) show the payoff (utility) functions for countries 1 and 2, respectively.

$$
\begin{aligned}
& V_{1}=\alpha L_{1}^{a}\left\{\left(1-\psi_{2} F_{2}\right) K_{1}+\psi_{1} F_{1} K_{2}^{1-\rho}\right\}^{b} \\
& V_{2}=\beta L_{2}^{c}\left\{\left(1-\psi_{1} F_{1}\right) K_{2}+\psi_{2} F_{2} K_{1}^{1-\rho}\right\}^{d}
\end{aligned}
$$

where $\psi_{1}, \psi_{2}=$ fighting technology $\left(0<\psi_{1}<1,0<\psi_{2}<1\right), \rho=$ friction of appropriation.

The payoff function for country 1 simply corresponds to its production using the non-appropriated portion of its own capital and the capital it steals from country 2. The terms $\psi_{1}, \psi_{2}$ represent the "effectiveness" of appropriation, which directly depends on the fighting technology of the two countries. If, for example, country 1 has better fighting technology (i.e. larger $\psi_{1}$ ), then each unit of its fighting effort results in more land and physical capital being appropriated from country 2 .

One can think of $\psi_{1}$ as a function $S$ of the levels of capital in the two countries, i.e. $\psi_{1}=$ $S\left(K_{1}, K_{2}\right)$. Note that $K_{1}$ and $K_{2}$ also capture the capital intensity of an economy, given that the total labor stock is normalized to 1 . It is also natural to assume that $\partial S / \partial K_{1}>0$ and $\partial S / \partial K_{2}<0$. Capital-intensive countries have better fighting technologies and are thus more difficult to conquer.

We believe that technology has relatively little independent impact on the modern conflict behavior of states, however. At least part of the role of technology is to substitute for increasingly expensive labor in the military forces of advanced industrial nations (Gartzke 2001). There is also an increasing gulf between optimal force structures for achieving victory on the battlefield and for policing and suppressing occupied populations (Headrick 1981, Biddle 1998). Control of territory is labor intensive, requiring the suppression of local resistance movements. The difficulties faced by 
U.S. forces in Vietnam and more recently in Iraq illustrate this point. While fighting technology can be viewed as a critical determinant of conflict (van Creveld 1989, Biddle 2004), we argue, and later show, that the effect of military technology, independent of economic development, is not large. The motivations for war, and the physical ability to sustain operations far from home often prove of much greater significance than the presence of sophisticated weapons technology (Lieber 2005). Given these arguments, we assume that the fighting technology for territorial conquest is a concave function of the capital in a country, $\partial^{2} S /\left(\partial K_{1}\right)^{2}<0$. In other words, capital intensity increases fighting power, but at a decreasing rate. Similar increases in the capital-intensiveness of both countries in a dyad should also tend to cancel each other out. Hence, $\partial S / \partial K_{1} \approx-\partial S / \partial K_{2}$.

The term $\rho$ represents "friction" associated with appropriation. Similar to "iceberg transport costs" in gravity models of trade, friction corresponds to the destruction of capital through the act of appropriation. Friction can result from indirect factors such as a loss of local or international goodwill or know-how or as a direct result of fighting (casualties, infrastructure deterioration).

Applying the time constraint (1) to the payoff functions (4a) and (4b), and simplifying, yields, respectively, equations (5a) and (5b):

$$
\begin{aligned}
& V_{1}=\alpha L_{1}^{a}\left\{\left(1-\psi_{2}\left(1-L_{2}\right)\right) K_{1}+\psi_{1}\left(1-L_{1}\right) K_{2}^{1-\rho}\right\}^{b} \\
& V_{2}=\beta L_{2}^{c}\left\{\left(1-\psi_{1}\left(1-L_{1}\right)\right) K_{2}+\psi_{2}\left(1-L_{2}\right) K_{1}^{1-\rho}\right\}^{d}
\end{aligned}
$$

Taking the first derivative of $V_{1}$ with respect to $L_{1}$, and of $V_{2}$ with respect to $L_{2}$, we obtain the first-order conditions, and the reaction functions for the two countries, displayed in (6a) and (6b).

$$
\begin{aligned}
& R F_{1}\left(L_{2}\right)=L_{1}=\frac{a}{a+b}\left[\frac{\left(1-\psi_{2}\left(1-L_{2}\right)\right) K_{1}}{\psi_{1} K_{2}^{1-\rho}+1}\right] \\
& R F_{2}\left(L_{1}\right)=L_{2}=\frac{c}{c+d}\left[\frac{\left(1-\psi_{1}\left(1-L_{1}\right)\right) K_{2}}{\psi_{2} K_{1}^{1-\rho}+1}\right]
\end{aligned}
$$

The first thing to note is that the time spent for productive activities of a given country is greater if the opponent also spends more time on production and less on appropriation (i.e. $L_{1}$ is 
increasing in $L_{2}$ in equation (6a), and $L_{2}$ is increasing in $L_{1}$ in equation (6b)). This relationship is reflected by positively sloped reaction functions (illustrated later in Figure 2), as in a "coordinationgame" or a "common-interest-game." This result also accords nicely with the finding of "zones of peace" among geographically proximate developed countries (Kacowicz 1998, Gleditsch 2003).

The unique Nash equilibrium corresponds to the intersection of the two reaction functions. Given their positive, linear slope we focus on the reaction functions for comparative statics, as every factor that increases their intercepts and slopes directly increases equilibrium labor levels. ${ }^{14}$

We can see from equation (6a) that the level of productive activities of country 1 is positively related to country 1's own capital endowment and is negatively related to the capital endowment of country 2. A higher capital endowment makes productive activities more efficient and thus more appealing compared to fighting. In contrast, a higher capital endowment of an opponent makes the opponent a more attractive target. Accordingly, country 1 will spend more time on appropriation and less on production if country 2 possesses a large capital stock. The invasion of Kuwait by Iraq in 1990 illustrates the appeal of conquering valuable inputs to production. Further, the level of productive activities $L_{1}$ decreases in the fighting technology $\psi_{1}$ of country 1 (being stronger makes a country more inclined to attempt to engage in appropriation) and in the fighting technology $\psi_{2}$ of country 2 (a strong opponent is more bellicose, discouraging country 1 from productive activity). Finally, a larger friction of appropriation $\rho$ deters fighting and makes production more attractive.

There are three distinct avenues through which economic development can affect conflict. First, development corresponds with an increase in total factor productivity. Second, development results in a higher capital stock endowment. The two effects are linked in the sense that a productivity increase today leads to both higher standards of living and a larger capital endowment in the future. Third, by increasing capital-intensity, development improves fighting technology (recall, $\partial S / \partial K_{1}>$ $0)$. This third effect has the potential to confound the two positive effects of development. Yet, this should not be the case, given that improvements in military technology lag capital accumulation.

With the above framework, it is now possible to examine two sets of relationships: the general impact of development on territorial conflict and initiator versus target effects. We do so below.

\footnotetext{
${ }^{14} \mathrm{We}$ focus on interior solutions where $L_{1}<1, L_{2}<1$. Equilibrium labor levels are: $L_{1}=$ $A \frac{C K_{1}^{\rho} K_{2}\left(1-\psi_{1}\right)+K_{2}^{1-\rho} \psi_{1}+K_{1}(1-(1-C)) \psi_{2}}{\left(K_{2}^{1-\rho}-A C K_{1}^{\rho} K_{2}\right) \psi_{1}}$ and $L_{2}=C \frac{A K_{2}^{\rho} K_{1}\left(1-\psi_{2}\right)+K_{1}^{1-\rho} \psi_{2}+K_{2}(1-(1-A)) \psi_{1}}{\left(K_{1}^{1-\rho}-A C K_{2}^{\rho} K_{1}\right) \psi_{2}}$, where $A \equiv \frac{a}{(a+b)}, C \equiv \frac{c}{(c+d)}$.
} 


\subsection{Hypotheses: Development and Territorial Conflict}

Proponents of a link between economic development and peace point to the declining value of occupation, the increasing cost or risk of invasion, or the redundancy of conquest given the relatively free availability of goods (Brooks 2005, Rosecrance 1996). As we have pointed out, however, these claims are not generally supported by systematic studies. Still, these arguments appear to us to be not so much wrong, as overly categorical, asserting in effect that modernity reduces all motives for militarized violence. Territory (and the resources in and on land) has been a major source of warfare, but land is not the only item over which states fight (Vasquez 1993, Hensel 2000). Sovereign powers also use force to impose their will on other states or populations, making the targets of influence change policy or leadership rather than taking physical possession of territory. Since arguments made by advocates of a link between development or technology and peace only impinge on the economic value of territory, other reasons for fighting are not directly affected.

Our model predicts that economic development leads to a Nash equilibrium with a low level of fighting over territory. We first study the general effect of development on the incentives for territorial war, without distinguishing initiator versus target effects. Consider a general increase in development in both countries (for simplicity, we use the same relative increase in development). Total factor productivities and capital levels in both countries increase. Further, as the rise in development is symmetric in both countries, the effects on fighting technology cancel out (recall that fighting technologies $\psi_{1}$ and $\psi_{2}$ depend on the relative development levels of the counties, and hence, when both countries experience development to the same extent their relative fighting power does not change, i.e. $\left.\partial S / \partial K_{1} \approx-\partial S / \partial K_{2}\right)$. Total factor productivities of the two countries do not enter the reaction functions, but capital stock levels do. The more developed country 1 (higher $K_{1}$ ), the greater country 1's incentives to produce and the lower its incentives to attack country

2. In contrast, country 2's development is associated with a higher level of $K_{2}$, which enters the denominator of the right hand side of equation (6a). Thus, as country 2 develops, country 1 cares less about its own production and more about appropriation. However, as there is a destruction cost associated with appropriation, the first effect dominates. We can see this when we multiply capital 
levels in both countries by a common factor $\Delta>1$ (i.e., the symmetric increase in development).

$$
\begin{gathered}
L_{1}^{\prime}=\frac{a}{a+b}\left[\frac{\left(1-\psi_{2}\left(1-L_{2}\right)\right) \Delta K_{1}}{\psi_{1}\left(\Delta K_{2}\right)^{1-\rho}}+1\right]=\frac{a}{a+b}\left[\frac{\left(1-\psi_{2}\left(1-L_{2}\right)\right) K_{1}}{\psi_{1} K_{2}{ }^{1-\rho}} \Delta^{\rho}+1\right]>L_{1} \\
L_{2}^{\prime}=\frac{c}{c+d}\left[\frac{\left(1-\psi_{1}\left(1-L_{1}\right)\right) \Delta K_{2}}{\psi_{2}\left(\Delta K_{1}\right)^{1-\rho}}+1\right]=\frac{c}{c+d}\left[\frac{\left(1-\psi_{1}\left(1-L_{1}\right)\right) K_{2}}{\psi_{2} K_{1}{ }^{1-\rho}} \Delta^{\rho}+1\right] \Delta^{\rho}>L_{2}
\end{gathered}
$$

Clearly, this leads to higher levels of labor effort, $L_{1}^{\prime}$ and $L_{2}^{\prime}$. The model predicts that developed countries have more incentives to produce, and fewer incentives to pursue territorial appropriation.

Hypothesis 1 Developed countries are less likely to experience territorial disputes.

Figure 2 illustrates the effect of a symmetrical increase in development for particular parameter values. ${ }^{15}$ Note that the result of hypothesis 1 is general and holds for all other parameter values as well. The solid gray line corresponds to the reaction function of country 1 , while the solid black line represents the reaction function of country 2. Initially, development is low $\left(K_{1}=K_{2}=1\right)$. The Nash equilibrium is $E$, meaning that both countries spend roughly a third of their time producing and two thirds appropriating. Suppose now that a worldwide increase in economic development leads to $K_{1}^{\prime}=K_{2}^{\prime}=3$. This results in a shift to the right of country 1's reaction function (gray dotted line) and to an upward shift of country 2's reaction function (black dotted line). The Nash equilibrium is then $E^{\prime}$, where countries spend almost two thirds of their time for production, and the rest for appropriation. Increasing capitalization reduces incentives for countries to appropriate.

\subsection{Hypotheses: Initiators versus Targets}

Explanations suggest variously that development makes it harder to generate profit from occupied territory (the supply side "bitter pill" argument), or that potential initiators find fighting less profitable than production (demand side "prosperous pacifists" theories). Distinguishing between supply and demand effects is important in understanding how development influences war and peace (Most \& Starr 1990). Brooks makes a supply side argument when he emphasizes the difficulty of maintaining modern economies under occupation: "it is almost certain that conquest

\footnotetext{
${ }^{15}$ The following parameter values are assumed for illustration: $a /(a+b)=c /(c+d)=0.25, \psi_{1}=\psi_{2}=0.8, \rho=0.5$.
} 


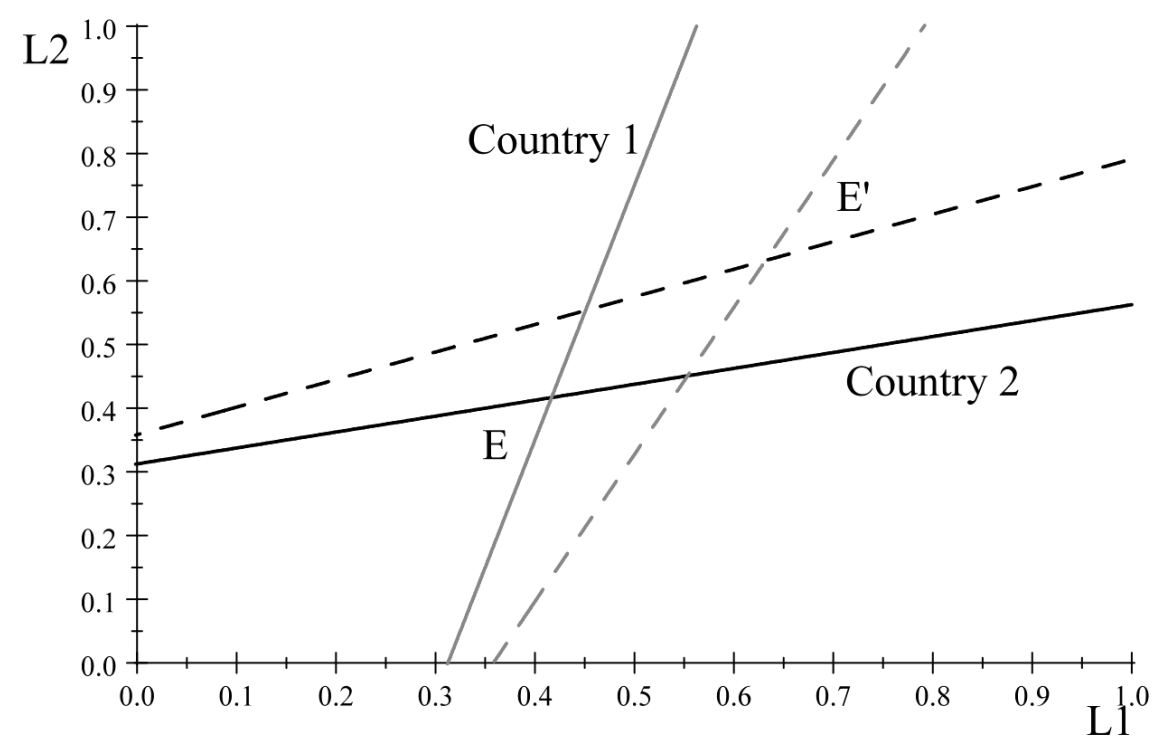

Figure 2: The impact of development on territorial conflict

will significantly reduce the available pool of risk capital within the conquered territory ..." (1999, page 657). Angell, on the other hand, presents a demand side argument when he notes that German invaders looting the Bank of England would cause harm to the German economy "so serious as to constitute a loss immensely greater than the value of the loot obtained" (1933, page 107). ${ }^{16}$

Supply side arguments stress characteristics of the target. If development makes profits more difficult to extract from conquered countries, then developed states should be less likely to be attacked by other states, whether the attackers are developed our not. ${ }^{17}$ The demand side rationale suggests instead that only developed initiators are more reluctant to seek territory through force.

Our framework allows a prediction about which of these rationales is more likely. To distinguish target versus initiator effects, we can focus on one country, say country 1 , and compare the effects of an increase in development in country 1 with an increase in development in country 2 . If a positive development shock in country 1 leads to relatively stronger labor effort, this would conform with demand-side explanations (i.e., developed countries are less likely to initiate territorial conflict).

\footnotetext{
${ }^{16}$ Angell, like others, offers a mix of both supply side and demand side arguments. "As the only feasible policy in our day for a conqueror to pursue is to leave the wealth of a territory in the possession of its occupants, it is a fallacy, an illusion to regard a nation as increasing its wealth when it increases its territory" (1933, page 91).

${ }^{17}$ See, Liberman (1996) for evidence that occupied industrialized states can be made to turn a profit. The appropriate question, however, is whether profits acquired under conquest exceed those expected from peacetime trade.
} 
Conversely, if a positive development shock in country 2 has stronger effects, this is consistent with supply-side arguments (i.e., developed countries are less likely to be targets of territorial conflict).

Let us first discuss the impact of development in country 1 on the country's labor supply $L_{1}$. There are three effects: Development increases $K_{1}$ (more capital), increases $\psi_{1}$ (easier conquest of the opponent) and decreases $\psi_{2}$ (more difficult target). The partial derivatives are $\partial L_{1} / \partial K_{1}>0$, $\partial L_{1} / \partial \psi_{1}<0, \partial L_{1} / \partial \psi_{2}<0$. The first and the third effect increase the incentives for labor effort: More capital increases the marginal productivity of labor and being a "bitter pill" for enemy conquest protects production. This is partially offset by the second effect that deters labor effort: Being stronger increases incentives for conquering territory. However, given that fighting technology is a concave function of capital-intensiveness, we know that effect one (larger capital) always outweighs effect two (stronger fighting capacities). ${ }^{18}$ Hence, overall it must always hold that increasing a country's economic development decreases its appetite for initiating territorial conflict.

Hypothesis 2 (demand) Developed countries are less likely to initiate territorial disputes.

We can also analyze the effect of an increase in country 2's development on the incentives for labor in country 1 . There are again three effects: Development in country 2 increases $K_{2}$ (more attractive target for country 1 ), increases $\psi_{2}$ (country 2 has stronger incentives for appropriation) and decreases $\psi_{1}$ (country 2 becomes a "bitter pill"). The partial derivatives are $\partial L_{1} / \partial K_{2}<0$, and as before $\partial L_{1} / \partial \psi_{2}<0$ and $\partial L_{1} / \partial \psi_{1}<0$. The first two effects depress country 1's incentives for labor: The capital-rich country 2 becomes a more attractive target, and given that the now militarily strong country 2 poses a greater threat to country 1's capital also production becomes less worthwhile (as the marginal productivity of labor increases in the available capital). The third effect runs counter the first two: Country 2 is harder to conquer, which drives country 1 towards productive activities. Hence, the overall effect of country 2's development on country 1's labor efforts is ambiguous: Two effects pull country 1 towards more territorial disputes with country 2, while one effect drives it towards less territorial disputes. Overall, these effects should tend to

\footnotetext{
${ }^{18}$ This can easily be seen in equation (6a): Concavity implies that a given increase in capital, $\Delta K_{1}$, leads to a less than proportional increase in fighting power, $\widetilde{\Delta} \psi_{1}$ (i.e. $\Delta>\widetilde{\Delta}$ ). As $\Delta K_{1}$ is in the numerator, and $\widetilde{\Delta} \psi_{1}$ in the denominator of the fraction $\frac{\left(1-\psi_{2}\left(1-L_{2}\right)\right) \Delta K_{1}}{\widetilde{\Delta} \psi_{1} K_{2}^{1-\rho}}$, this expression becomes unambiguously larger as country 1 develops.
} 
cancel out so that developed countries are neither more nor less likely to be targets of territorial conflict. What is clear however, is that even if supply-factors should on the whole lead developed countries to be less prone to become targets, this effect will be smaller than the unambiguous demand-side effects of developed countries tending to be less willing to initiate territorial conflict. This can be seen from the fact that $\partial L_{1} / \partial K_{1}>0>\partial L_{1} / \partial K_{2}$, and that the effects on relative fighting strengths are likely to cancel out (as in both cases there is one effect related to fighting capability that pulls towards more conflict, while the other effect pulls states towards less conflict).

Hypothesis 3 (supply) Developed states should be about as likely to be targets of territorial disputes (even if development decreases the likelihood of becoming a target of territorial conflict, the effect should be smaller than the tendency for developed countries not to initiate territorial disputes).

Figure 3 illustrates these findings for the same parameter values as in Figure 2, ${ }^{19}$ but now we assume that the positive development shock is limited to country $1\left(K_{1}^{\prime}=3, K_{2}^{\prime}=1\right)$. The choices country 1 and country 2 make again move the Nash equilibrium from E to E'. Country 1's labor time is now strongly increased - and the time spent on conflict is decreased - and where the effect on country 2 is ambiguous and small. Demand-side effects are larger than supply-side effects.

The focus of this paper lies in disentangling supply versus demand effects of development for territorial conflict. However, as we transition from the theoretical to the empirical, it becomes necessary to discuss how our model relates to non-territorial conflict. As argued above, the military technology for territorial conquest and control is labor intensive. Increases in available capital only have small effects on the ability to control conquered territories. Hence, it makes sense to think of the fighting technology as being a concave function of the capital-intensiveness of the economy.

In contrast, the fighting technology for non-territorial conflicts over policy are arguably quite different. Where the goal is to punish a leader for adopting hostile policies, or to induce regime change in a given country, for example, without controlling territory over the long term, tanks and planes may be more important than soldiers or marines. The high-tech U.S. Air Force possesses a comparative advantage in the kinds of punitive actions designed to compel policy change, but it

\footnotetext{
${ }^{19}$ The relative fighting capabilities of the two states must change, given that now only one country experiences the positive development shock. For the sake of exposition, we assume $\psi_{1}^{\prime}=0.9$ and $\psi_{2}^{\prime}=0.7$.
} 


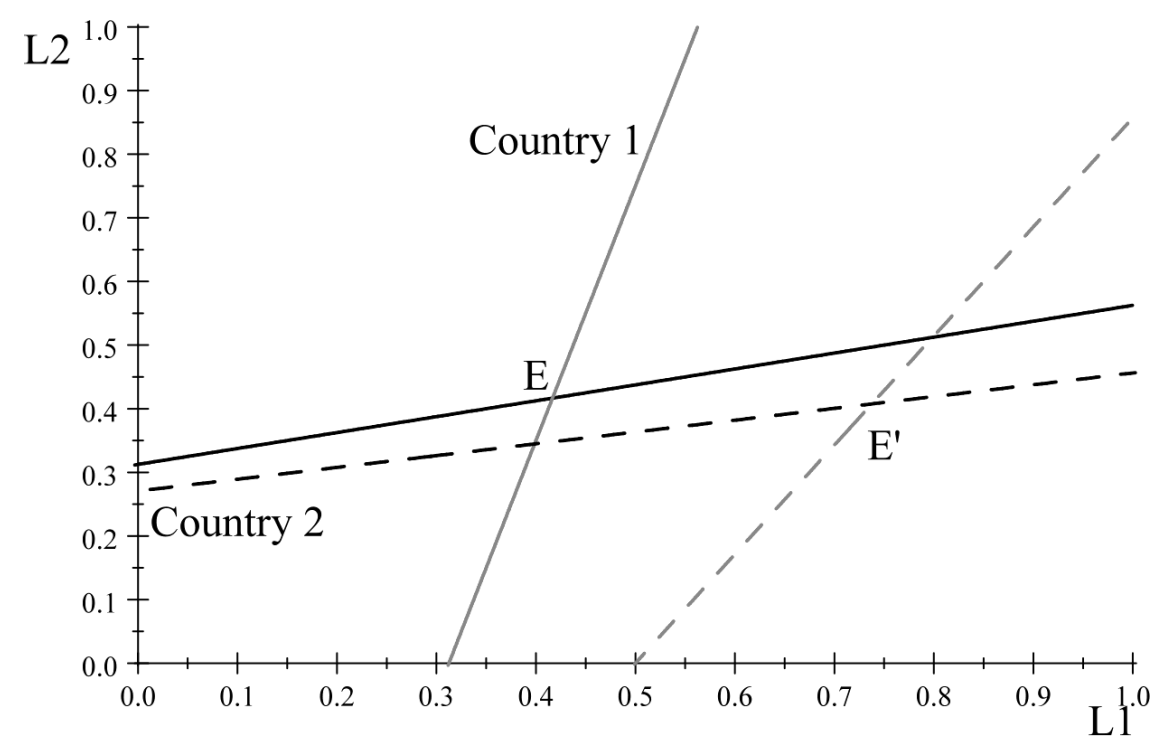

Figure 3: The impact of an increase in development in country 1 only

has been much less effective when trying to control territory or unruly populations. Scud missiles, Islamist insurgents, and Saddam Hussein himself all evaded detection by airpower, while bridges, airports and armored units experienced devastating destruction. In terms of our model, it makes sense to think about the fighting technology for policy disputes as being a convex, rather than concave function of capital-intensiveness. Formally, $\psi_{1}=\widetilde{S}\left(K_{1}, K_{2}\right)$, where $\partial \widetilde{S} / \partial K_{1}>0$ and $\partial^{2} \widetilde{S} /\left(\partial K_{1}\right)^{2}>0$. If the resulting increase in $\psi_{1}$ is large enough in equation (6a), then in country 1 a positive development shock could decrease its $L_{1}$, and cause country 1 to fight harder over policy.

\section{Research Design}

We examine the impact of economic development on militarized interstate disputes (MIDs) and several other indicators of territorial conflict with samples ranging from the post-World War II period to the period from the end of the Napoleonic Wars (1816 - 2000). We use directed dyads to differentiate potential initiators from targets and evaluate the hypotheses. Reliable data on gross domestic product (GDP) is available only from 1945 onward. We extend the analysis by using two cruder indicators of development, energy consumption and iron \& steel production. Both long-term indicators are well documented in other studies (Singer et al. 1972; Singer 1987; Correlates of War 
Project 2005). We estimate coefficients using probit in Stata with Huber/White robust standard errors. Independent variables are lagged by one year to limit the effects of endogeneity. We also use the Beck, et al. (1998) method of temporal splines to control for duration dependence. ${ }^{20}$

\subsection{Data}

Data for the study come from several sources, but we begin with a set of variables from the data management software program EUGene (Bennett \& Stam 2000, 2001). Unless otherwise stated, variables used in the analysis are coded according to procedures detailed in EUGene documentation.

\subsubsection{Dependent Variables}

The main dependent variable is coded from the MIDs dataset of militarized threats, deployments, uses of force, or wars (Gochman \& Maoz 1984; Jones et al. 1996). EUGene includes a dummy for MID "initiation," where the variable is coded (1) if a dispute is initiated by state A in a directed dyad, and (0) reflects either no dispute, or one initiated by state B. The directed dyad research design used here allows states to appear as either potential initiator or target in each dyad year.

We also replicate a critical portion of our analysis on three datasets that specifically identify conflicts over territory. Huth \& Allee $(2002,2003)$ construct a dataset of territorial disputes for most countries over the period 1919-1995. The main objective of their analysis is to evaluate democratic peace theories (Huth and Allee do not directly assess the impact of economic development on territorial conflicts). Huth and Allee code for the initiator and target of each conflict, allowing directed dyadic analysis. Tir, et al. (1998) identify all territorial changes in the period 1816-1996 that involve at least one nation-state as defined by the COW criteria. $^{21}$ These data distinguish between territorial revisions involving militarized violence and those that do not, but they do not specify the initiator or target. ${ }^{22}$ As such, we can only directly evaluate claims about the nondirectional effect of development on territorial conflict, but this can offer additional support for other findings. Finally, we examine an indicator of territorial conflict from the Issue Correlates of

\footnotetext{
${ }^{20}$ We have prepared a Stata "do" file that replicates all aspects of data construction and quantitative analysis.

${ }^{21}$ See, Correlates of War Project $(2005 b)$ for a discussion of the COW coding rules for system membership. See, Fazal (2004) and Gleditsch \& Ward (1999) for criticism on the coding decisions used by the COW project.

${ }^{22}$ Goertz \& Diehl (1992) offer a more detailed discussion of the territorial revision data.
} 
War project (ICOW), which identifies territorial, riparian, and maritime claims in the Americas (Hensel 2001). ICOW codes for claims as opposed to conflicts. The relationship between claimant and conflict initiator is ambiguous. Still, the ability to conduct additional tests is appealing.

\subsubsection{Independent Variables}

Economic development: We use three indicators of development: 1.) GDP/Pop. measures a state's annual gross domestic product per capita (Gleditsch 2002). We take the natural log of GDP to control for heteroskedasticity. 2.) Energy Cons./Pop. comes from the COW National Material Capabilities dataset of total annual fuel consumption in coal-ton equivalents. 3.) Iron ES Steel/Pop. measures the quantity of iron or steel produced by a country in a given year. These measures are often-used proxies for GDP (c.f. Lipset 1959; Burkhart \& Lewis-Beck 1994; Hegre et al. 2001).

Military Technology: We adopt an indicator that is convenient and which we believe is sufficiently accurate for the purposes of this study. We divide annual defense spending from the COW National Material Capabilities dataset (CINC) by the number of military personnel for each country. ${ }^{23}$ This creates a statistic analogous to GDP per capita for the military that should tell us which armies have advanced weaponry, communication, transport, and logistics capabilities, and which do not.

Trade: Interdependent states may be less (Oneal et al. 1996, 2003; Polachek 1980, 1992, 2002; Polachek \& McDonald 1992; Polachek, Robst \& Chang 1999; Russett \& Oneal 2001), or more (Hirschman 1945; Barbieri 1996, 2003) likely to fight each other, or there may be no effect of trade on disputes (Gartzke \& Li 2003; Gartzke et al. 2001). Given the close putative relationship between trade and economic development (Smith 1976[1776], Ricardo 1984[1821], Viner 1937, Rostow 1960), we include estimates of the effect of both bilateral and multilateral trade in this analysis (Gleditsch 2002). ${ }^{24}$ We also replace missing values of the trade variables with "0" to minimize listwise deletion (Oneal \& Russett 1997, Oneal \& Russett 1999), though this is not critical to establish our results.

\footnotetext{
${ }^{23}$ COW provides military expenditure data in nominal (current year) U.K. pounds (1816-1913) and U.S. dollars (1914-2000). We converted these data to real 2000 dollars using exchange rates and GDP deflators available on EH.net, (URL: http://eh.net/hmit/), and documented in Johnston \& Williamson (2005) and Officer (2004, 2005).

${ }^{24}$ Results are the same using models that omit the trade variable, or that include only openness or bilateral trade.
} 
Democracy: Polity data provide two eleven-point indexes of regime type based on formal constraints on the executive (AUTOC) and institutional support for democracy (DEMOC) (Jaggers \& Gurr. 1995, Gurr et al. 1989). We prepare monadic values by taking the difference between DEMOC and AUTOC, adding 10 and divide by 2 to yield the $0-10$ range of Polity variables. We examine both the monadic values and higher and lower scores in each dyad (Oneal et al. 2003; Oneal \& Russett 1996).

Geographic Contiguity and Distance: Neighbors fight more than states that are geographically distant. In part, this can be explained by opportunity. Yet, there is a greater likelihood of fighting among contiguous dyads independent of distance (Diehl 1985). Contiguity is a dichotomous variable for states that share a land border or are separated by less than 150 miles of water. We also include a variable measuring the metric distance between dyad members. Distance is the natural logarithm of the great circle distance between state capitals (in some cases other cities are used).

Major Power Status: Major powers tend to be more active at the international level. There is also a danger that the relationship between development and conflict might be confounded by major power politics. Maj. Power codes the presence (1), or absence (0) of a major power.

Allies: Alliances are intended to affect conflict behavior. Alliance is a dichotomous variable for the presence of an alliance in the dyad, based on the COW Alliance Dataset (Singer \& Small 1966, Small \& Singer 1990, Gibler \& Sarkees 2004). We examine both all alliances and just defense pacts.

Capabilities: Capabilities determine the ability of states to project power and conduct warfare independent of national income. We assess capabilities using the COW CINC scores of each state in the dyad. CINC scores are computed as the weighted average of a state's share of total system population, urban population, energy consumption, iron and steel production, military manpower and military expenditures. $C I N C$ represents the CINC score for each state in the directed dyad. ${ }^{25}$

\footnotetext{
${ }^{25} \mathrm{An}$ interaction term between the $C I N C$ variables is seldom significant and does not alter the results.
} 
Oil and Mountains: Research on civil war emphasizes the effect of geographic terrain (Buhaug \& Gates 2002; Collier et al. 2004) and resources (Collier \& Hoeffler 2002, 2004) on conflict. The same factors should prove salient for states contemplating invasion. Similarly, some prizes are greater than others. Oil would seem to be a particularly appealing target for conquest. ${ }^{26}$ We use data from Fearon \& Laitin (2003) to identify which countries are mountainous, and/or are oil-rich.

The Middle East: Regional heterogeneity has been identified as an important potential problem in cross-sectional analysis of international relations (Lemke 2002, 2003a, 2003b). In particular, the Middle East is often said to be an outlier. ${ }^{27}$ Many of the countries in the region also possess unusual oil wealth that skews average national income statistics. While not necessary for the results, it seems appropriate to examine whether our findings are robust to heterogeneous regional effects (Lai 2006).

Temporal Dependence: Finally, we control for temporal dependence using the Beck et al. (1998) technique. We construct four splines for each dependent variable, interpolated from a dummy matrix coding the lag between directed dyad years of conflict initiation or onset.

\section{Results}

The results are detailed in three tables. In the first and second tables, the dependent variable is MID initiation by state A. Table 1 uses GDP per capita to measure development. ${ }^{28}$ Table 2 offers a longer time-series using energy consumption. Table 3 assesses other indicators of territorial conflict.

Model 1 in Table 1 lists the probit coefficient estimates for a model of the general effects of economic development and military technology on all dispute initiations by state A. Consistent with previous research, coefficient estimates for GDP/Pop $A$ and $G D P / P o p B$ are not statistically

\footnotetext{
${ }^{26}$ A recent study by de Soysa, et al. (2009) shows that oil states are no more likely to be the targets of attacks.

${ }^{27} \mathrm{We}$ examined a set of regional dummies and found that the Middle East is the most conflict prone, followed by Asia, with Africa and the Americas not statistically atypical in their behavior, and Europe least disputatious. The Middle East dummy thus serves as a convenient (and compact) assessment of regional outlier effects. Sørli et al. (2005) show that civil conflict is no more common in the Middle East than standard statistical models would predict.

${ }^{28}$ Maddison (2003) offers historical GDP data, but the sample is quite limited. Results are similar.
} 


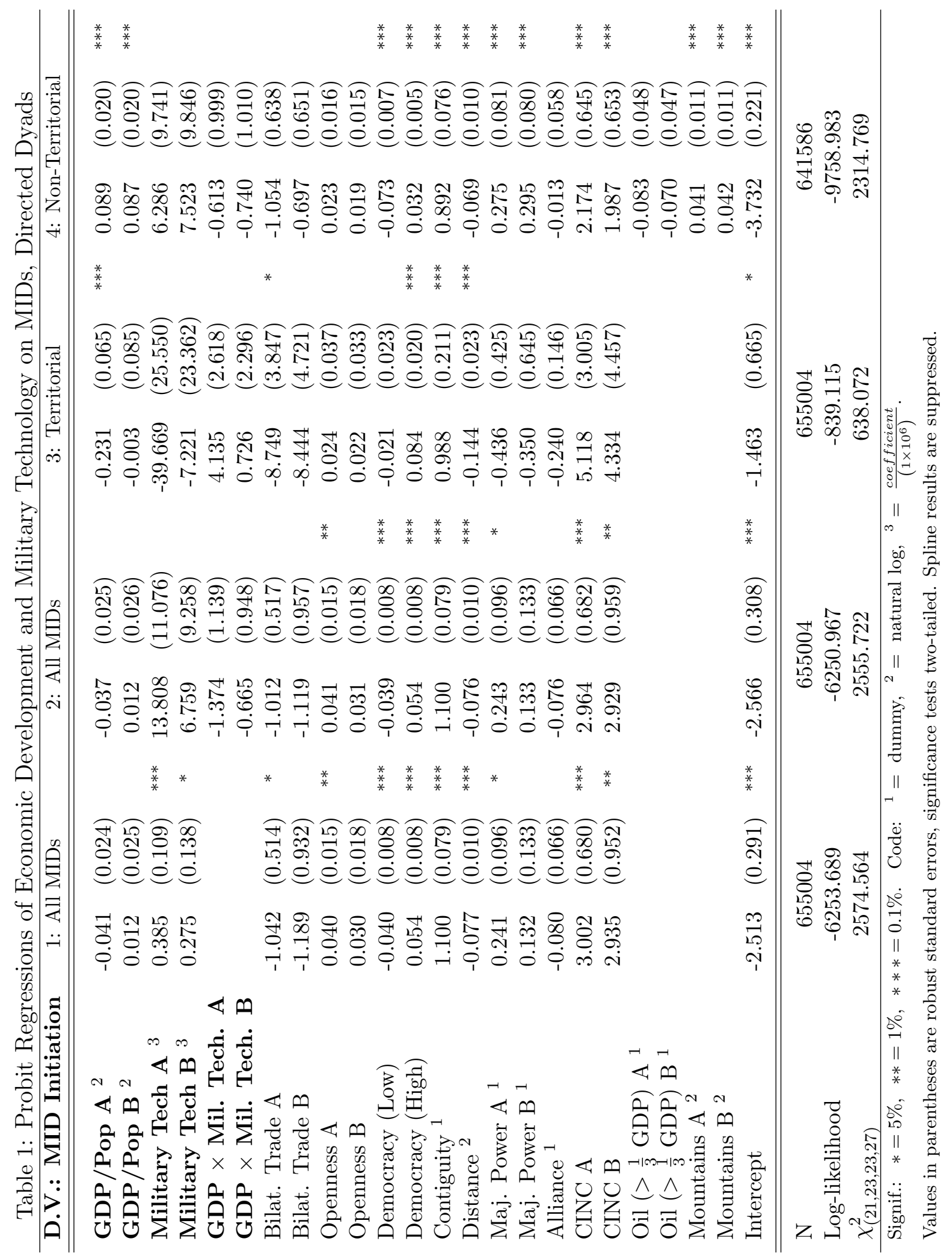


different from zero. Development has no discernible effect on potential initiators or targets. Conversely, military technology appears to be an important influence on whether states fight, with both military technology variables significantly increasing dispute behavior. On first reflection, the results for the Military Tech variables appear to contradict our assertion that military technology does not matter much for war or peace. However, Model 1 also treats technology and development as independent processes. We need to allow for the possibility that the apparent effect of military technology is really a product of economic development. Model 2 adds an interaction term between a country's level of development and its military technology. Once the two variables are allowed to interact, we see that neither variable significantly influences the likelihood of interstate conflict.

Our theory of development and conflict suggests the need to differentiate between fights over resources and the exercise of influence over policy outcomes. In Model 3, we limit the coding of MIDs to territorial disputes. Without changing any other aspect of the statistical model, we now see that developed states are much less likely to initiate conflicts. Conversely, economic development appears to have no impact on the propensity to become a target of territorial aggression. Nor do the military technology variables have any independent impact in this or subsequent regressions. As suggested by hypothesis 2, developed states are much less likely to initiate a dispute over territory. Consistent with hypothesis 3, developed countries are no less likely to become the targets of militarized disputes concerning territory. Supply side arguments implying that development leads to bitter pill effects in which states are unprofitable to conquer are not supported (Brooks 2005).

Developed countries do not appear reluctant to use militarized aggression for other purposes. Indeed, as Model 4 reveals, developed countries are significantly more likely to be both the initiators and targets of conflict over non-territorial issues. Both monadic development coefficients (which are virtually identical) are positive and significant, meaning that there are equivalent, independent contributions from each state in the dyad. Developed states A are more likely to initiate a dispute regardless of the characteristics of state $\mathrm{B}$, but are most likely to experience a MID with other developed states. Many of the disputes in which developed countries are more likely to participate involve joining or patron-client relationships, where policy interests play a larger role than territory.

Other variables in the four models in Table 1 help to ensure that our findings are not the 
product of the most obvious spurious relationships. ${ }^{29}$ There are no consistent findings involving trade. Bilateral and openness values for state A are statistically significant in two of the models. The trade dependence of the target state is largely irrelevant in explaining conflict. Contiguity and distance behave as expected, while the dyadic alliance variable is never statistically significant.

Some of the most interesting findings in Table 1 involve differences across the four models. Both Democracy variables are statistically significant, with the exception of Democracy (Low) in Model 3. The effect of democracy on conflict appears to vary between territorial and non-territorial disputes. Similarly, major power initiators and both capabilities variables are statistically insignificant for territorial contests. If power determines state interests, we might expect that state A's CINC score matters, but not that of state B. Conversely, deterrence theory (Snyder 1961; Mearsheimer 1983, 2001) implies that the CINC score of state B should negatively (and significantly) predict MIDs.

Model 4 also includes four additional variables meant to capture the appeal of conquest or the difficulty of fighting. These variables are not included in Model 3 because they were not statistically significant. Interestingly, oil wealth has no effect on militarized disputes, but mountainous countries are more conflict prone over policy. Differences seem to persist when terrain gets rougher, perhaps because such mountainous places constitute safe havens for peoples or groups with heterodox views.

Table 2 repeats much of the analysis conducted in Table 1, but uses energy consumption in place of GDP per capita. The trade variables and the indicators of "conquerability" and oil are omitted due to the lack of data. We also drop the military technology variables, as they have little effect on the analysis. However, we add a Middle East dummy to assess regional heterogeneity. ${ }^{30}$ Population weighted energy consumption performs in much the same way as GDP per capita. There is no statistically significant effect in the larger sample when disputes are all evaluated together, but evaluating development only in the territorial or non-territorial samples leads to quite a different picture. In Model 6, the energy consumption of initiators, but not of targets, is negatively associated with territorial disputes (hypotheses 2 and 3). Similarly, in Model 7, as discussed above, the energy consumption of both initiators and targets increases non-territorial militarized conflict.

A recent study by Senese (2005) focusing on interactions between territory and contiguity

\footnotetext{
${ }^{29}$ Results of regressions containing only the key development and technology variables are substantially the same.

${ }^{30}$ Adding the Middle East dummy to the territorial and non-territorial models in Table 1 does not affect results.
} 
Table 2: Probit Regressions of Energy Consumption on MIDs, Directed Dyads

\begin{tabular}{|c|c|c|c|}
\hline D.V.: MID Initiation & 5: All MIDs & 6: Territorial & 7: Non-Territorial \\
\hline Energy Cons./Pop. A (ln) & $\begin{array}{r}-0.018 \\
(0.019)\end{array}$ & $\begin{array}{c}-0.277^{* * *} \\
(0.084)\end{array}$ & $\begin{array}{l}0.046^{\text {*** }} \\
(0.013)\end{array}$ \\
\hline Energy Cons./Pop. B (ln) & $\begin{array}{r}-0.004 \\
(0.018)\end{array}$ & $\begin{array}{r}-0.088 \\
(0.067)\end{array}$ & $\begin{array}{l}0.046^{\text {*** }} \\
(0.013)\end{array}$ \\
\hline Democracy (Low) & $\begin{array}{c}-0.035^{* * *} \\
(0.005)\end{array}$ & $\begin{array}{r}-0.020 \\
(0.016)\end{array}$ & $\begin{array}{c}-0.054^{\text {*** }} \\
(0.005)\end{array}$ \\
\hline Democracy (High) & $\begin{array}{l}0.043^{* * *} \\
(0.006)\end{array}$ & $\begin{array}{l}0.069^{* * *} \\
(0.017)\end{array}$ & $\begin{array}{l}0.036 \\
(0.004)\end{array}$ \\
\hline Contiguity (dummy) & $\begin{array}{l}0.762^{\text {*** }} \\
(0.060)\end{array}$ & $\begin{array}{l}1.007^{* * *} \\
(0.150)\end{array}$ & $\begin{array}{l}0.652^{\text {*** }} \\
(0.057)\end{array}$ \\
\hline Distance $(\ln )$ & $\begin{array}{c}-0.075^{* * *} \\
(0.008)\end{array}$ & $\begin{array}{c}-0.0911^{* * *} \\
(0.019)\end{array}$ & $\begin{array}{c}-0.072^{\text {*** }} \\
(0.007)\end{array}$ \\
\hline Maj. Power A & $\begin{array}{l}0.366^{\text {*** }} \\
(0.056)\end{array}$ & $\begin{array}{c}0.103 \\
(0.174)\end{array}$ & $\begin{array}{l}0.352^{\text {*** }} \\
(0.051)\end{array}$ \\
\hline Maj. Power B & $\begin{array}{c}0.129 \\
(0.077)\end{array}$ & $\begin{array}{c}-0.044 \\
(0.241)\end{array}$ & $\begin{array}{l}0.357^{* * *} \\
(0.052)\end{array}$ \\
\hline Alliance (dummy) & $\begin{array}{c}-0.093^{*} \\
(0.046)\end{array}$ & $\begin{array}{r}-0.119 \\
(0.091)\end{array}$ & $\begin{array}{c}-0.085^{*} \\
(0.040)\end{array}$ \\
\hline CINC A & $\begin{array}{l}1.994^{* * *} \\
(0.325)\end{array}$ & $\begin{array}{c}1.870 \\
(1.188)\end{array}$ & $\begin{array}{l}1.982^{\text {*** }} \\
(0.310)\end{array}$ \\
\hline CINC B & $\begin{array}{l}1.812^{\text {**** }} \\
(0.493)\end{array}$ & $\begin{array}{c}1.251 \\
(1.736)\end{array}$ & $\begin{array}{l}1.825 \text { *** } \\
(0.331)\end{array}$ \\
\hline Middle East & $\begin{array}{l}0.458^{* * *} \\
(0.072)\end{array}$ & $\begin{array}{l}0.488^{* * *} \\
(0.138)\end{array}$ & $\begin{array}{l}0.410 \text { *** } \\
(0.051)\end{array}$ \\
\hline Intercept & $\begin{array}{c}-2.565^{* * *} \\
(0.063)\end{array}$ & $\begin{array}{c}-3.351^{* * *} \\
(0.156)\end{array}$ & $\begin{array}{c}-2.268^{\text {*** }} \\
(0.061)\end{array}$ \\
\hline $\mathrm{N}$ & 984510 & 984510 & 984510 \\
\hline Log-likelihood & -12256.985 & -1427.833 & -18014.711 \\
\hline$\chi_{(16,16,16)}^{2}$ & $2797.33^{* * *}$ & $438.43^{* * *}$ & $3568.84^{* * *}$ \\
\hline
\end{tabular}


finds that development increases the tendency of states to escalate to militarized disputes. Our research design differs from Senese (directed dyads versus dyadic analysis, different variables and variable constructions). Senese also combines territorial and non-territorial MIDs in the analysis (2005, pages 772-773). The most salient difference, however, may be the use by Senese (2005) of territorial claims data from Huth \& Allee $(2002,2003)$. Because territorial claims constitute a sub-sample, the implicit assumption in the research design is that developed and developing states demand territorial changes at about the same rate. If instead developed states have fewer reasons to demand territorial revisions, then they can appear to be more likely to escalate, even though they are less likely to experience conflict in general over territory. ${ }^{31}$ We argue that developed states make fewer territorial demands than developing countries. Developed states tend already to control the places and populations that identify with the nation, making revisionist claims less likely.

We next take a closer look at the connection between economic development and territorial claims. Table 3 summarizes findings using other measures of territorial conflict and the third indicator of development, iron \& steel production. ${ }^{32}$ The three regressions in Table 3 are similar to Model 6 in Table 2, but rely on other data sources to construct the dependent variable. Model 8 presents probit coefficient estimates and standard errors using data from Huth \& Allee (2002, 2003) to construct the dependent variable. As these results reveal, economically developed states are much less likely to initiate conflicts over territory. While Huth and Allee find that democratic initiators are less likely to fight over territory, the effect of democracy on the potential initiator is not statistically significant in Model 8. Instead, democratic targets appear more likely to be challenged over territorial issues. This discrepancy could be due to the absence of controls for economic development in Huth \& Allee (2002), though their analysis of democracy is more detailed.

Model 9 examines the effect of development on territorial conflict using data from Tir et al. (1998). Development is again found to reduce the penchant for conflict over territory (hypothesis 1). Most of the other relationships are largely as before, though Democracy B, Maj. Power B, and CINC A are no longer statistically significant. The largest difference is that the development level

\footnotetext{
${ }^{31}$ As Senese (2005, page 778) cogently points out, wars between non-contiguous states may appear more likely because, while non-contiguous dyads are less likely to experience any kind of dispute, those that do engage in violence are more likely to be considerably resolved and thus more likely to precipitate high levels of casualties.

${ }^{32}$ We also evaluated these models using the energy consumption variable, which yielded similar results.
} 
Table 3: Probit Regressions of Iron \& Steel Production on Territorial Conflicts

\begin{tabular}{|c|c|c|c|}
\hline D.V.: Various & $\begin{array}{r}\text { 8: Huth Terr } \\
\text { Conflicts } \\
\end{array}$ & $\begin{array}{r}\text { 9: Diehl Terr } \\
\text { Revisions }\end{array}$ & $\begin{array}{r}\text { 10: ICOW Terr } \\
\text { Disputes } \\
\end{array}$ \\
\hline Iron \& Steel/Pop. A (ln) & $\begin{array}{c}-1.338^{* *} \\
(0.453)\end{array}$ & $\begin{array}{c}-1.578 \text { ** } \\
(0.566)\end{array}$ & $\begin{array}{c}-1.479^{* * * *} \\
(0.423)\end{array}$ \\
\hline Iron \& Steel/Pop. B (ln) & $\begin{array}{c}0.205 \\
(0.209)\end{array}$ & $\begin{array}{c}-1.5744^{\text {** }} \\
(0.573)\end{array}$ & $\begin{array}{c}-0.697^{*} \\
(0.354)\end{array}$ \\
\hline Democracy A & $\begin{array}{c}-0.017 \\
(0.010)\end{array}$ & $\begin{array}{c}0.021 \\
(0.012)\end{array}$ & $\begin{array}{c}0.025 \\
(0.015)\end{array}$ \\
\hline Democracy B & $\begin{array}{l}0.035^{* *} \\
(0.012)\end{array}$ & $\begin{array}{c}0.018 \\
(0.012)\end{array}$ & $\begin{array}{l}0.040^{*} \\
(0.020)\end{array}$ \\
\hline Contiguity (dummy) & $\begin{array}{l}1.845^{* * *} \\
(0.156)\end{array}$ & $\begin{array}{l}0.971^{\text {*** }} \\
(0.142)\end{array}$ & $\begin{array}{l}1.569^{* * *} \\
(0.224)\end{array}$ \\
\hline Distance (ln) & $\begin{array}{c}-0.048 \text { ** } \\
(0.017)\end{array}$ & $\begin{array}{c}-0.039 \text { ** } \\
(0.015)\end{array}$ & $\begin{array}{c}-0.008 \\
(0.023)\end{array}$ \\
\hline Maj. Power A & $\begin{array}{c}0.094 \\
(0.195)\end{array}$ & $\begin{array}{c}0.289 \\
(0.175)\end{array}$ & $\begin{array}{c}-1.746^{* * * *} \\
(0.253)\end{array}$ \\
\hline Maj. Power B & $\begin{array}{l}0.8977^{* * *} \\
(0.175)\end{array}$ & $\begin{array}{c}0.311 \\
(0.175)\end{array}$ & $\begin{array}{c}-1.0322^{* * *} \\
(0.255)\end{array}$ \\
\hline Alliance (dummy) & $\begin{array}{c}-0.093 \\
(0.086)\end{array}$ & $\begin{array}{c}-0.188 \\
(0.103)\end{array}$ & $\begin{array}{c}-0.010 \\
(0.105)\end{array}$ \\
\hline CINC A & $\begin{array}{l}2.744^{*} \\
(1.324)\end{array}$ & $\begin{array}{c}1.148 \\
(1.082)\end{array}$ & $\begin{array}{l}4.115^{* * *} \\
(1.210)\end{array}$ \\
\hline CINC B & $\begin{array}{l}-0.728 \\
(1.166)\end{array}$ & $\begin{array}{c}0.828 \\
(1.108)\end{array}$ & $\begin{array}{l}5.270^{* * * *} \\
(0.953)\end{array}$ \\
\hline Middle East & $\begin{array}{l}0.451^{* * *} \\
(0.120)\end{array}$ & $\begin{array}{l}0.551^{* * *} \\
(0.128)\end{array}$ & \\
\hline Intercept & $\begin{array}{l}-2.864^{* * *} \\
(0.150)\end{array}$ & $\begin{array}{l}-3.743^{* * *} \\
(0.141)\end{array}$ & $\begin{array}{l}-1.454^{* * *} \\
(0.216)\end{array}$ \\
\hline $\mathrm{N}$ & 754932 & 954245 & 175767 \\
\hline Log-likelihood & -17708.526 & -927.574 & -6840.893 \\
\hline$\chi_{(16,16,15)}^{2}$ & $945.65^{* * *}$ & $593.76^{* * *}$ & $500.45^{* * *}$ \\
\hline
\end{tabular}


of the target is now statistically significant in reducing territorial conflict. This can be explained by the fact that the Tir et al. (1998) dyadic coding does not identify an initiator. As such, the effects of development on initiator or target cannot be specifically identified and are instead diluted. Still, the general relationship appears robust enough to persist even with a loss of precision.

Finally, Hensel (2001) provides an indicator of territorial conflict from the Issue Correlates of War project (ICOW) project. Model 9 shows once again that states are less likely to become involved in conflicts if the potential initiator is economically developed. The economic status of the target is also relevant to whether states experience conflict. While ICOW code initiators and targets, the coding is for territorial claims as opposed to conflicts. The behavior of claimants appears slightly different from, but not incompatible with, that of disputants. We find that the results are again supportive of the claim that developed states are less prone to seek to alter the status quo distribution of territory. Our results also account for the disparity between our study and that of Senese (2005). The tendency of developed states to reflect the territorial status quo, and not to seek to conquer territory, further supports our findings that developed countries care less about resource conquest, while being if anything more willing to compel in the policy sphere.

\section{Conclusion}

Development is not synonymous with peace. Average national income has no simple monotonic effect on militarized conflict. In particular, by increasing state capacity, economic development expands the ability of prosperous states to impose themselves on their neighbors. The evidence of this provided here is that developed states more often engage in certain kinds of aggressive behavior. Developed states fight over disputed polices more often regardless of whether as an initiator or target. Developed countries concern themselves with more of the world's problems, and are thus drawn in as participants in a wider array of policy or regime-oriented conflicts.

Development reduces the utility of territorial theft. It is now cheaper in most cases for the most advanced countries to leave government to local authorities and to purchase what they need through global markets. This is not a characteristic of the land itself. Indeed, after controlling for the effects of power and proximity, developed states as potential targets are no less likely to 
be the subject of territorial aggression. Rather, development works on the willingness of potential initiators of territorial conflict, reducing their interest in taking through force what can be had through exchange. Trade is cheap. Occupation (though unfortunately not war) is expensive.

We began by noting that territory has traditionally been a major impetus for interstate war. The historical record provides numerous examples of big states gobbling up their smaller neighbors. Yet, small states still existed throughout history. What kept big states from eliminating small states all together? While there are several factors, including use as buffers ${ }^{33}$ norms of appropriate international behavior (Bull 1995; Wendt 1999, page 283-284), and adept diplomacy (Fox 1959), one should also acknowledge the role of material constraints in thwarting unlimited expansion. From time immemorial, states have failed to extend their domains because they could not. Rome stopped at the Rhine, not because its leaders had misgivings about the moral content of (more) empire, but because Rome's legions could stretch themselves no further (Wells 2002). ${ }^{34}$

Today, the world's most powerful and prosperous nations are less constrained than they are conditioned by economic development. Force, while at least as feasible as ever before, is certainly less profitable, at least when it comes to territorial conquest. Wealth has not created bitter pills, nations immune to the Hobbesian inclinations of other nations. Instead, prosperous pacifists have emerged, nations that no longer desire conquest, even if compelling other countries through force remains a viable element of policy making. Prosperous pacifists ensure a special, more limited kind of peace, one in which the traditional logic of occupation and territorial control can no longer be justified on domestic economic grounds. We can only hope that pacific incentives will continue.

\footnotetext{
${ }^{33}$ Fazal (2002) shows that small states that act as buffers are less likely to survive as independent sovereign nations.

${ }^{34}$ Tolerance of buffer states may be endogenous. Both Ancient Rome and the series of Chinese empires adopted explicit strategies of creating buffer polities by "civilizing" and co-opting settled tribal groups on their borders.
} 


\section{References}

Angell, Norman. 1933. The Great Illusion. New York: Putnam.

Ashley, Richard K. 1980. The Political Economy of War and Peace. New York: Nichols.

Barbieri, Katherine. 1996. "Economic Interdependence: A Path to Peace or a Source of International Conflict?" Journal of Peace Research 33(1):29-49.

Barbieri, Katherine. 2003. The Liberal Myth. Ann Arbor, MI: University of Michigan Press.

Beck, Neal, Jonathan Katz \& Richard Tucker. 1998. "Taking Time Seriously: Time-series-Cross-section Analysis with a Binary Dependent Variable." American Journal of Political Science 42(4):1260-1288.

Bennett, D. Scott \& Allan C. Stam. 2000. "EUGene: A Conceptual Manual." International Interactions 26(2):179-204.

Bennett, D. Scott \& Allan C. Stam. 2001. "EUGene: Expected Utility and Data Management Program, version 2.250." Computer Program. The Pennsylvania State University and Dartmouth University.

Biddle, Stephen. 1998. "Assessing Theories of Future Warfare." Security Studies 88(1):1-74.

Biddle, Stephen. 2004. Military Power: Explaining Victory and Defeat in Modern Battle. Princeton, NJ: Princeton University Press.

Blainey, Geoffrey. 1973. The Causes of War. New York: Free Press.

Boehmer, Charles \& David Sobek. 2005. "Violent Adolescence: State Development and the Propensity for Militarized Interstate Conflict." Journal of Peace Research 42(1):5-26.

Boulding, Kenneth. 1962. Conflict and Defense. New York: Harper \& Row.

Brooks, Stephen. 1999. "The Globalization of Production and the Changing Benefits of Conquest." Journal of Conflict Resolution 43(5):646-670.

Brooks, Stephen. 2005. Producing Security: Multinational Corporations, Globalization, and the Changing Calculus of Conflict. Princeton, NJ: Princeton University Press.

Buhaug, Halvard \& Nils Petter Gleditsch. 2006. The Death of Distance?: The Globalization of Armed Conflict. In Territoriality and Conflict in an Era of Globalization, ed. Miles Kahler \& Barbara Walter. Cambridge: Cambridge University Press.

Buhaug, Halvard \& Scott Gates. 2002. "The Geography of Civil War." Journal of Conflict Resolution 39(4):417-433.

Bull, Hedley. 1995. The Anarchical Society: A Study of Order in World Politics. Second ed. New York: Columbia University Press.

Burkhart, Ross E. \& Michael S. Lewis-Beck. 1994. "Comparative Democracy: The Economic Development Thesis." American Political Science Review 88(4):903-910.

Carr, E.H. 1939. The Twenty Years' Crisis: 1919-1939. London: Macmillan.

Choucri, Nazli \& Robert C. North. 1975. Nations in Conflict: National Growth and International Violence. San Francisco: W.H. Freeman.

Choucri, Nazli \& Robert C. North. 1989. Lateral Pressure in International Relations: Concept and Theory. In Handbook of War Studies., ed. Manus I. Midlarsky. Boston, MA: Unwin-Hyman pp. 289-326.

Cobden, Richard. 1903[1867]. Political Writings of Richard Cobden. Vol. I London: T. Fisher Unwin.

Collier, Paul \& Anke Hoeffler. 2002. "On the Incidence of Civil War in Africa." Journal of Conflict Resolution 46(1):13-28. 
Collier, Paul \& Anke Hoeffler. 2004. "Greed and Grievance in Civil War." Oxford Economic Papers 56(4):563595.

Collier, Paul, Anke Hoeffler \& Måns Söderbom. 2004. "On the Duration of Civil War." Journal of Peace Research 41(3):253-273.

Correlates of War Project. 2005a. "National Material Capabilities Data Documentation, V. 3.0." Codebook.

Correlates of War Project. 2005b. State System Membership List, v2004.1. Online ed.

de Soysa, Indra, Erik Gartzke \& Tove Grete Lin. 2009. "Oil, Blood, and Strategy: How Petroleum Influences Interstate Disputes." Typescript. The Norwegian University of Science and Technology and the University of California, San Diego.

Diehl, Paul. 1985. "Contiguity and Military Escalation in Major Power Rivalries, 1816-1980." Journal of Politics 47(4):1203-1211.

East, Maurice A. \& Phillip M. Gregg. 1967. "Factors Influencing Cooperation and Conflict in the International System." International Studies Quarterly 11(3):244-269.

Elbadawi, Ibrahim \& Håvard Hegre. 2008. "Globalization, Economic Shocks, and Internal Armed Conflict." Defense and Peace Economics 19(1):37-60.

Elbadawi, Ibrahim \& Nicholas Sambanis. 2002. "How Much War Will We See?: Explaining the Prevalence of Civil War." Journal of Conflict Resolution 46(3):307-334.

Ellingsen, Tanja. 2000. "Colorful Community or Ethnic Witches' Brew?: Multiethnicity and Domestic Conflict During and After the Cold War." Journal of Conflict Resolution 44(2):228-249.

Fazal, Tanisha. 2002. "Born to Lose and Doomed to Survive: State Death and Survival in the International System." Stanford University. Dissertation.

Fazal, Tanisha. 2004. "State Death in the International System." International Organization 58(2):311-344.

Fearon, James D. 1995. "Rationalist Explanations for War." International Organization 49(3):379-414.

Fearon, James D. \& David D. Laitin. 2003. "Ethnicity, Insurgency, and Civil War." American Political Science Review 97(1):75-90.

Fox, Annette Baker. 1959. The Power of Small States: Diplomacy in World War II. Chicago: University of Chicago Press.

Gaddis, John Lewis. 1992a. How Relevant was U.S. Strategy in Winning the Cold War? Carlisle Barracks, PA: Strategic Studies Institute, U.S. Army War College.

Gaddis, John Lewis. 1992b. "International Relations Theory and hte End of the Cold War." International Security 17(3):5-58.

Gaddis, John Lewis. 2005a. Strategies of Containment: A Critical Appraisal of American National Security Policy During the Cold War. New York: Oxford University Press.

Gaddis, John Lewis. 2005b. The Cold War: A New History. New York: Penguin.

Gartzke, Erik. 2001. "Democracy and the Preparation for War: Does Regime Type Affect States' Anticipation of Casualties?" International Studies Quarterly 45(3):467-484.

Gartzke, Erik. 2006. Globalization, Economic Development, and Territorial Conflict. In Territoriality and Conflict in an Era of Globalization, ed. Miles Kahler \& Barbara Walter. Cambridge: Cambridge University Press pp. 156-186.

Gartzke, Erik. 2007. "The Capitalist Peace." American Journal of Political Science 51(1):166-191. 
Gartzke, Erik \& Dominic Rohner. 2009. "To Conquer or Compel: Economic Development and Interstate Conflict." University of California, San Diego and the University of York. Typescript.

Gartzke, Erik \& Quan Li. 2003. "War, Peace, and the Invisible Hand: Positive Political Externalities of Economic Globalization." International Studies Quarterly 47(4):561-586.

Gartzke, Erik, Quan Li \& Charles Boehmer. 2001. "Investing in the Peace: Economic Interdependence and International Conflict." International Organization 55(2):391-438.

Gellner, Ernest. 1983. Nations and Nationalism. Ithaca, NY: Cornell University Press.

Gibler, Douglas \& Meredith Reid Sarkees. 2004. "Measuring Alliances: The Correlates of War Formal Interstate Alliance Dataset, 1816-2000." Journal of Peace Research 41(2):211-222.

Gilpin, Robert. 1981. War and Change in World Politics. New York: Cambridge University Press.

Glaser, Charles L. 2004. "When Are Arms Races Dangerous?" International Security 28(4):44-84.

Gleditsch, Kristian S. 2002. "Expanded Trade and GDP Data." Journal of Conflict Resolution 46(5):712724 .

Gleditsch, Kristian S. 2003. All Politics is Local: The Diffusion of Conflict, Integration, and Democratization. Ann Arbor, MI: University of Michigan Press.

Gleditsch, Kristian S. \& Michael D. Ward. 1999. "Interstate System Membership: A Revised List of the Independent States since 1816." International Interactions 25:393-413.

Gochman, Charles S. \& Zeev Maoz. 1984. "Militarized Interstate Disputes, 1816-1976: Procedure, Patterns, and Insights." Journal of Conflict Resolution 28(4):585-615.

Goertz, Gary \& Paul F. Diehl. 1992. Territorial Changes and International Conflict. New York: Routledge.

Gurr, Ted Robert, Keith Jaggers \& Will H. Moore. 1989. "Polity II: Political Structures and Regime Change." Codebook. University of Maryland.

Headrick, Daniel R. 1981. The Tools of Empire: Technology and European Imperialism in the Nineteenth Century. Oxford: Oxford University Press.

Hegre, Håvard. 2000. "Development and the Liberal Peace: What Does it Take to Be a Trading State." Journal of Peace Research 37(1):5-30.

Hegre, Håvard, Tanja Ellingsen, Scott Gates \& Nils Petter Gleditsch. 2001. "Toward a Democratic Civil Peace?: Democracy, Political Change, and Civil War, 1816-1992." American Political Science Review 95(1):33-48.

Henderson, Errol A. 1997. "Culture or Contiguity: Ethnic Conflict, the Similarity of States, and the Onset of War 1820-1989." Journal of Conflict Resolution 41(5):649-668.

Hensel, Paul. 2001. "Contentious Issues and World Politics: The Management of Territorial Claims in the Americas, 1816-1992." International Studies Quarterly 45(1):81-109.

Hensel, Paul R. 2000. Territory: Theory and Evidence on Geography and Conflict. In What Do We Know About War?, ed. John A. Vasquez. New York: Rowman \& Littlefield pp. 57-84.

Hirschman, Albert O. 1945. National Power and the Structure of Foreign Trade. Berkeley: University of California Press.

Hobson, John A. 1938[1905]. Imperialism. Ann Arbor, MI: University of Michigan Press.

Huth, Paul K. \& Todd L. Allee. 2002. "Domestic Political Accountability and the Escalation and Settlement of International Disputes." Journal of Conflict Resolution 46(6):754-790. 
Huth, Paul K. \& Todd L. Allee. 2003. The Democratic Peace and Territorial Conflict in the Twentieth Century. Cambridge: Cambridge University Press.

Jaggers, Keith \& Ted R. Gurr. 1995. "Transitions to Democracy: Tracking Democracy's 'Third Wave' with the Polity III Data." Journal of Peace Research 32(4):469-482.

Jepperson, Ronald L., Alexander Wendt \& Peter J. Katzenstein. 1996. Norms, Identity, and Culture in National Security. In The Culture of National Security: Norms and Identity in World Politics, ed. Peter J. Katzenstein. New York: Columbia University Press p. ***.

Johnston, Louis D. \& Samuel H. Williamson. 2005. "The Annual Real and Nominal GDP for the United States, 1790 - Present." Economic History Services .

Jones, Daniel, Stuart Bremer \& J. David Singer. 1996. "Militarized Interstate Disputes, 1816-1992: Rationale, Coding Rules, and Empirical Patterns." Conflict Management and Peace Science 15(2):163-213.

Kacowicz, Arie M. 1998. Zones of Peace in the Third World: South America and West Africa in Comparative Perspective. Albany, NY: State University of New York Press.

Kaysen, Carl. 1990. "Is War Obsolete?: A Review Essay." International Security 14(4):42-64.

Kennedy, Paul M. 1989. Rise and Fall of the Great Powers: Economic Change and Military Conflict from 1500 to 2000. New York: Random House.

Kuznets, Simon. 1966. Modern Economic Growth. New Haven: Yale University Press.

Kuznets, Simon. 1973. "Modern Economic Growth: Findings and Reflections." American Economic Review 63(3):247-258.

Lai, Brian. 2006. "An Empirical Examination of Religion and Conflict in the Middle East, 1950-1992." Foreign Policy Analysis 2(1):21-36.

Leeds, Brett Ashley. 2003. "Alliance Reliability in Times of War: Explaining State Decisions to Violate Treaties." International Organization 57:801-827.

Lemke, Douglas. 2002. Regions of War and Peace. Cambridge: Cambridge University Press.

Lemke, Douglas. 2003a. "African Lessons for International Relations Research." World Politics 56(1):114138.

Lemke, Douglas. 2003b. "Development and War." International Studies Review 5(4):55-63.

Lenin, V.I. 1965. Imperialism, the Highest Stage of Capitalism. Beijing, PRC: Foreign Languages Press.

Levy, Jack S. 1981. "Alliance Formation and War Behavior: An Analysis of the Great Powers, 1495-1975." Journal of Conflict Resolution 25(4):581-613.

Liberman, Peter. 1996. Does Conquest Pay?: The Exploitation of Occupied Industrial Societies. Princeton, NJ: Princeton University Press.

Lieber, Kier A. 2005. War and the Engineers: The Primacy of Politics over Technology. Cornell University Press.

Lipset, Seymour M. 1959. "Some Social Requisites of Democracy: Economic Development and Political Development." American Political Science Review 53(1):69-105.

Long, David. 1996. Towards A New Internationalism: The International Theory of J.A. Hobson. Cambridge: Cambridge University Press.

Luxemburg, Rosa. 1971. The Mass Strike, The Political Party and the Trade Unions, and The Junius Pamphlet. New York: Harper \& Row. 
Maddison, Angus. 2003. The World Economy: Historical Statistics. Paris: Organization for Economic Co-operation and Development.

Maoz, Zeev \& Bruce Russett. 1992. "Alliances, Contiguity, Distance, Wealth, and Political Stability: Is the Lack of Conflict Among Democracies a Statistical Artifact?" International Interactions 17(3):245-268.

McGuire, Martin C. \& Mancur Olson. 1996. "The Economics of Autocracy and Majority Rule: The Invisible Hand and the Use of Force." Journal of Economic Literature 34(1):72-96.

Mearsheimer, John J. 1983. Conventional Deterrence. Ithaca, NY: Cornell University Press.

Mearsheimer, John J. 2001. The Tragedy of Great Power Politics. New York: W.W. Norton.

Moore, Barrington. 1966. Social Origins of Dictatorship and Democracy. Boston: Beacon.

Morrow, James D. 1989. "Capabilities, Uncertainty, and Resolve: A Limited Information Model of Crisis Bargaining." American Journal of Political Science 33(2):941-972.

Morton, Rebecca B. 1999. Methods and Models: A Guide to the Empirical Analysis of Formal Models in Political Science. Cambridge: Cambridge University Press.

Most, Benjamin A. \& Harvey Starr. 1990. "Opportunity, Willingness, and the Diffusion of War." American Political Science Review 84(1):47-67.

Mueller, John. 1989. Retreat from Doomsday: The Obsolescence of Major War. New York: Basic Books.

Officer, Lawrence H. 2004. "Exchange Rate Between the United States Dollar and the British Pound, 1791-2004." Economic History Services .

Officer, Lawrence H. 2005. "The Annual Real and Nominal GDP for the United Kingdom, 1086-2004." Economic History Services .

Olson, Mancur. 1993. "Dictatorship, Democracy, and Development." American Political Science Review $87(3): 567-576$.

Oneal, John R. \& Bruce Russett. 1997. "The Classical Liberals Were Right: Democracy, Interdependence, and Conflict, 1950-1985." International Studies Quarterly 41(2):267-293.

Oneal, John R. \& Bruce Russett. 1999. "The Kantian Peace: The Pacific Benefits of Democracy, Interdependence, and International Organizations." World Politics 52(1):1-37.

Oneal, John R., Bruce Russett \& Michael L. Berbaum. 2003. "Causes of Peace: Democracy, Interdependence, and International Organizations." International Studies Quarterly 47(3):371-393.

Oneal, John R., Frances H. Oneal, Zeev Maoz \& Bruce Russett. 1996. "The Liberal Peace: Interdependence, Democracy, and International Conflict, 1950-1985." Journal of Peace Research 33(1):11-28.

Osborne, Martin J. \& Ariel Rubinstein. 1994. A Course in Game Theory. Cambridge, MA: MIT Press.

Paine, Thomas. 1986[1776]. Common Sense. New York: Penguin.

Polachek, Solomon W. 1980. "Conflict and Trade." Journal of Conflict Resolution 24(1):55-78.

Polachek, Solomon W. 1992. Conflict and Trade: An Economics Approach to Political Interactions. In Economics of Arms Reduction and the Peace Process., ed. Walter Isard \& C.H. Anderton. Amsterdam: North Holland Press pp. 89-120.

Polachek, Solomon W. 2002. "Trade-Based Interactions: An Interdisciplinary Perspective." Conflict Management and Peace Science 19(2):1-21.

Polachek, Solomon W., John Robst \& Yuan-Ching Chang. 1999. "Liberalism and Interdependence: Extending the Trade-Conflict Model." Journal of Peace Research 36(4):405-422. 
Polachek, Solomon W. \& Judith McDonald. 1992. Strategic Trade and Incentives for Cooperation. In Disarmament, Economic Conversion and the Management of Peace., ed. M. Chatterji \& L. Forcey. New York: Praeger pp. 273-284.

Powell, Robert. 2002. "Bargaining Theory and International Conflict." Annual Review of Political Science $5: 1-30$.

Ricardo, David. 1984[1821]. Principles of Political Economy and Taxation. 3rd ed. London: Dent.

Richardson, Lewis F. 1960. Statistics of Deadly Quarrels. Pittsburgh, PA.: Quadrangle/Boxwood.

Rosecrance, Richard. 1985. The Rise of the Trading State: Commerce and Conquest in the Modern World. New York: Basic Books.

Rosecrance, Richard. 1996. "The Rise of the Virtual State." Foreign Affairs 75(4):45-61.

Rostow, W.W. 1960. The Stages of Economic Growth: A Non-communist Manifesto. Cambridge: Cambridge University Press.

Rowe, David M. 1999. "World Economic Expansion and National Security in Pre-World War I Europe." International Organization 53(2):195-231.

Rummel, Rudolph J. 1967. "Some Attributes and Behavioral Patterns of Nations." Journal of Peace Research 4(2):196-206.

Russett, Bruce \& John R. Oneal. 2001. Triangulating Peace: Democracy, Interdependence, and International Organizations. New York: Norton.

Senese, Paul. 2005. "Territory, Contiguity, and International Conflict: Assessing a New Joint Explanation." American Journal of Political Science 49(4):769-779.

Singer, J. David. 1987. "Reconstructing the Correlates of War Dataset on Material Capabilities of States, 1816-1985." International Interactions 14:115-132.

Singer, J. David \& Melvin Small. 1966. "Formal Alliances, 1815-1939: A Quantitative Description." Journal of Peace Research 3(1):1-32.

Singer, J. David, Stuart Bremer \& John Stuckey. 1972. Capability Distribution, Uncertainty, and Major Power War. In Peace, War, and Numbers., ed. Bruce M. Russett. Beverly Hills, CA: Sage pp. 19-48.

Slantchev, Branislav. 2003. "The Power to Hurt: Costly Conflict with Completely Informed States." American Political Science Review 97(1):123-133.

Small, Melvin \& J. David Singer. 1990. Formal Alliances, 1816-1965: An Extention of the Basic Data. In Measuring the Correlates of War. University of Michigan Press.

Smith, Adam. 1976[1776]. An Inquiry into the Nature and Causes of the Wealth of Nations. Chicago: University of Chicago Press.

Smith, Alastair. 1995. "Alliance Formation and War." International Studies Quarterly 39(4):405-425.

Snyder, Glenn H. 1961. Deterrence and Defense. Princeton, NJ: Princeton University Press.

Sørli, Mirjam E., Nils Petter Gleditsch \& Håvard Strand. 2005. "Why Is There So Much Conflict in the Middle East?" Journal of Conflict Resolution 49(1):141-165.

Strayer, Robert. 1998. Why Did the Soviet Union Collapse? Understanding Historical Change. New York: M.E. Sharpe.

Thompson, William R. 1982. "Phases of the Business Cycle and the Outbreak of War." International Studies Quarterly 26:301-311.

Thucydides. 1960. The History of the Peloponnesian War. London: Oxford University Press. 
Tilly, Charles. 1992. Coercion, Capital, and European States. Cambridge, MA: Blackwell.

Tir, Jaroslav \& Paul Diehl. 1998. "Demographic Pressure and Interstate Conflict: Linking Population Growth and Density to Militarized Disputes and Wars, 1930-89." Journal of Peace Research 35(3):319-339.

Tir, Jaroslav, Philip Schafer, Paul Diehl \& Gary Goertz. 1998. "Territorial Changes, 1816-1996: Procedures and Data." Conflict Management and Peace Science 16(1):89-97.

van Creveld, Martin. 1989. Technology and War: From 2000B.C. to the Present. New York: Free Press.

Van Evera, Stephen. 1994. "Hypotheses on Nationalism and War." International Security 18(4):5-39.

Vasquez, John A. 1993. The War Puzzle. Cambridge: Cambridge University Press.

Viner, Jacob. 1937. Studies in the Theory of International Trade. New York: Harper \& Brothers.

Wagner, R. Harrison. 2000. "Bargaining and War." American Journal of Political Science 44(3):469-484.

Wallace, Michael. 1979. "Arms Races and Escalation: Some New Evidence." Journal of Conflict Resolution 23:3-16.

Wallensteen, Peter, Birger Heldt, Mary B. Anderson, Stephen John Stedman \& Leonard Wantchekon. 2001. Conflict Prevention through Development Co-operation. Research Report No. 59 Uppsala, Sweden: Department of Peace and Conflict Research, Uppsala University.

Wells, Peter S. 2002. The Battle that Stopped Rome: Emperor Augustus, Arminius, and the Slaughter of the Legions in the Teutoburg Forest. New York: W.W. Norton.

Wendt, Alexander. 1999. Social Theory of International Politics. Cambridge: Cambridge University Press.

Zuk, Gary. 1985. "National Growth and International Conflict: A Reevaluation of Choucri and North's Thesis." Journal of Politics 47(1):269-281. 